\title{
Přenos laboratoře do terénu: Využití smíšených metod během terénního studia náboženství'
}

\author{
Bringing the Lab into the Field: Using Mixed Methods to Study \\ Religion in the Wild
}

Dimitris Xygalatas

\begin{abstract}
Despite the tremendous importance of religion for so many people, its study has been confined to isolated and fragmented academic pockets, while a coherent integrative framework is lacking. The Cognitive Study of Religion, which constitutes one of the most important approaches to religion to appear in recent decades, seeks to bridge the gap between the traditional study of religion and the natural sciences. However, scholars on both sides of this bridge have often been reluctant to meet each other in the middle, and rather seem to be waiting reluctantly (if at all) for the other party to cross over. The result is a fragmented field of study, which fails to exploit the potential of new scientific methods and discoveries. Focusing on the interplay between laboratory and field methods, I argue for an integrative approach that is both analytical and synthetic. In such an approach, the traditional qualitative methods of the humanities and the more quantitative ones of the behavioural sciences are not antagonistic but complementary.
\end{abstract}

KEYWORDS academic study of religion, anthropology, cognitive sciences, interdisciplinarity

\begin{abstract}
Pokud jste ve společnosti lidí různých profesí a někdo se vás zeptá, co děláte, na odpověd', že jste univerzitní profesor, se začnou tvářit znuděně. Pokud jste ve společnosti profesorů z různých kateder, a někdo se vás zeptá, jaký je váš obor, na odpověd', že filosofie, se začnou se tvářit znuděně. Pokud jste na filosofické konferenci a někdo se vás zeptá, na čem pracujete, na odpověd', že na filosofii náboženství...
\end{abstract}

(Nelson Pike, in Bambrough 1980: 289)

Náboženství je fascinujícím a zároveň i důležitým předmětem vědeckého bádání. Ve jménu své víry lidé často dělají skutečně podivuhodné věci. Postí se, zrríkají se sexuálních vztahů, chodí po žhavém uhlí, propichují si tělo jehlami, berou do rukou jedovaté hady a někdy dokonce zvolí dobrovolný odchod ze světa. Vystavují se obrovským rizikům a pro své náboženství obětují čas, peníze a další cenné zdroje. Všechny tyto př́klady představují velmi

Sociálni studia. Katedra sociologie FSS MU, 2/2013. S. 15-25. ISSN 1214-813X.

1 Tento článek vznikl v rámci projektu Laboratoř pro experimentální výzkum náboženství (LEVYNA, CZ.1.07/2.3.00/20.0048) spolufinancovaného Evropskou unií a státním rozpočtem České republiky. 
fascinující vzrušující projevy chování, nejenom pro senzačnost, kterou vzbuzují, ale především proto, že mají reálný vliv na životy lidí. Odměny, které náboženství slibují, zákazy, které požadují, náboženský fundamentalismus, násilí mezi náboženskými skupinami a vliv náboženství na politiku, vzdělávání a dokonce vědu mají zásadní dủsledky pro život prakticky každého člověka, at již se pokládá za náboženského či nikoli. Přesto, navzdory své zásadní důležitosti, hraje studium náboženství v akademickém prostředí jen marginální roli; religionistická pracovišš mají podfinancované rozpočty a přitahují pozornost stále menšího a menšího množství studentů. ${ }^{2}$ Proč tomu tak je? Určitě ne z důvodu nedostatečného zájmu veřejnosti o tuto oblast, který dokládá velké množství každoročně prodaných knih s tematikou náboženství, spirituality a ateismu. Domnívám se, že tento problém spočívá v samotné povaze akademického studia náboženství.

Pravdou je, že akademické studium náboženství má špatnou pověst kvůli způsobu, se kterým bylo - a z valné části doposud je - prováděno. Zatímco jiné disciplíny, např́íklad psychologie nebo sociologie, se zcela ztotožnily s vědeckými metodami a kritérii př́rodních a lékařských věd, studium náboženství se $\mathrm{v}$ jistém smyslu odmítlo rozvíjet a zůstává ve svých snahách roztř̌ššěné a izolované. Je izolované, protože je prováděno téměř výhradně v oblasti humanitních věd, bez jakéhokoli dialogu s ostatními disciplínami, a prakticky zcela ignoruje pozoruhodný pokrok ve vysvětlování lidského chování dosažený v ostatních oblastech výzkumu. Je rovněž roztř̌ššěné, protože př́mo pozorovatelné projevy chování a explicitně zastávané postoje, na kterých téměř výlučně staví, představují, pokud se jedná o pochopení náboženského - nebo jakéhokoli jiného - chování, pouze onen prŕslovečný vrcholek ledovce.

\section{Tradiční paradigma}

Většina badatelů tradičně zacházela s náboženstvím jako s jevem sui generis, který nelze propojit s žádnou jinou úrovní lidského chování ani ho na žádnou jinou úroveň redukovat (Otto 1923; Pals 1987; Eliade 1961; Sharma 2001). Ve světle tohoto pohledu nejsou metody využívané v jiných disciplínách ke studiu náboženství vhodné, a to si proto vyžaduje vlastní speciální metody. Badatelé studující náboženství by se měli předmětu svého studia spíše pokoušet rozumět a popisovat ho, než se jej snažit vysvětlit. Snaha vysvětlit náboženství povede jen k jeho „banalizaci“ nebo mine jeho „podstatu“ (at’ již jí míníme cokoli) (Pyysiäinen 2004: xiii-xxii). V konečném důsledku pak tento postoj spatřuje ve studiu náboženství výsadní hájemství teologů nebo, v lepším případě, podnik striktně omezený na oblast humanitních věd, a preferuje hermeneutické př́stupy před explanačními. Popřením kompetence a práva vytvářet vědecké teorie o náboženských jevech a odmítnutím přínosu prírodních věd pro vysvětlení a interpretaci náboženského jednání a chování (McCutcheon 1997) tento postoj fakticky uvrhl oblast studia náboženství do izolace a znepřátelil si badatele $\mathrm{z}$ ostatních vědních odvětví. Náboženství tak zůstává předmětem studia výhradně $\mathrm{v}$ oblasti humanitních věd. Ti, kdo jej studovali, bud'to přijali za svůj hermeneutický postoj a zcela se odvrátili

2 Autor zde reflektuje spíše situaci ve zbytku Evropy a světa. V České republice je situace o poznání lepší a religionistika jako studijní obor se těší stabilnímu zájmu studentů (pozn. překladatele). 
od jakéhokoli vysvětlení, nebo byli zaujati sociální funkcí náboženství a z velké části opomíjeli psychologické procesy a vlastnosti lidského mozku/mysli. Psychologové na straně druhé bud'to zcela upustili od vstupu do oblasti bádání, kde byl podle jejich názoru prováděn pouze tuctový výzkum, nebo se soustředili na specifické náboženské projevy jako mysticismus a extáze (James 1958), jako by tyto byly reprezentativními pro všechny projevy religiozity (Lawson 2000).

\section{Kognitivní př́stup}

Během posledních desetiletí byl podniknut pokus o smíření studia náboženství se studiem mysli, ze kterého vzešla svou povahou interdisciplinární kognitivní religionistika. Počátky této snahy lze nalézt ve zrodu kognitivní vědy, která se objevila v 50. letech 20. století jako nové paradigma studia mentálních procesů a postupně nahradila do té doby dominantní behaviorismus (Skinner 1938). „Kognitivní revoluce“ započala v oblasti výzkumu umělé inteligence (Turing 1950; McCarthy a kol. 1962; McCarthy a kol. 1969; Newell a kol. 1972; Newell a kol. 1958; Minski 1954; Herbert 1969) a studia paměti (Broadbent 1958; Miller 1956). V oblasti studia kultury byl nejvýznamnějším hráčem Noam Chomsky (1957), který požadoval přesun pozornosti „od chování a jeho projevů k systému poznávání, které do tohoto chování vstupuje“ (1959). Chomsky prokázal, že důležité aspekty osvojování si jazyka jsou důsledkem univerzálních schopností lidského mozku, a zasadil tak konečný úder Skinnerovu radikálnímu behaviorismu, který v řeči spatřoval osvojený zvyk (Chomsky 1986). Snažil se prokázat existenci vrozené lidské jazykové schopnosti, „univerzální gramatiky“, která leží v základech gramatiky jakéhokoli konkrétního jazyka, a pokračoval v představení své prominentní teorie transformační-generativní gramatiky, jež poskytla model vrozeného poznání podmiňujícího lidskou schopnost hovořit a rozumět jazyku. Pro Chomského tedy byla lingvistika v konečném důsledku psychologickým počinem směřujícím $\mathrm{k}$ podrobnému pochopení biologicky ukotvených principů mysli, které omezují možnou podobu všech přirozeně vzniklých jazyků. Brzy na to začala být i mimo lingvistiku věnována zvýšená pozornost studím, které se zaměřovaly spíše na výzkum obecností v lidském chování než jeho různých projevů a pátraly po „univerzální gramatice“ ležící v základech sémantiky konkrétních kulturních jevů (Berlin a Kay 1969; Hays 1983; Brown 1984; Atran 1990).

První hlasy vybízející ke kognitivně orientovanému studiu náboženského chování se začaly ozývat v průběhu 70. let 20. století (Lawson 1976; Staal 1979a, 1979b) a největší dopad měla $v$ tomto ohledu vlivná kniha Dana Sperbera (1975) věnovaná symbolismu $\mathrm{v}$ antropologii. Sperber vystavil kritice existující sémiotické př́stupy $\mathrm{k}$ symbolismu a v jeho době dominantní přístup strukturální antropologie a přišel s myšlenkou, že symbolismus je lépe chápat ne jako systém abstraktních znaků a jejich významů s vlastními pravidly, ale spíše jako součást našich běžných mentálních procesů uvažování o okolním světě. V roce 1996 pak zdůraznil roli kognitivních omezení, která ovlivňují rozšířenost kulturních reprezentací, a brzy nato učinil analogii mezi šiřením kulturních představ a šiřrením virů $\mathrm{v}$ jednotlivých populacích. Představil tak „epidemiologický př́stup“ ke studiu kulturních jevů, který poskytuje základní východiska k výzkumu toho, jakým způsobem jsou určité představy vybírány $\mathrm{k}$ přenosu, zatímco jiné upadají v zapomnění (Sperber 1996). V opozici vůči teorii 
Richarda Dawkinse o přenosu kulturních reprezentací v podobě memů (Dawkins 1976) zastával Sperber postoj, že jednotlivé reprezentace nejsou přenášeny formou přesné replikace, ale v procesu neustálých transformací a opětovných reprezentací. Smyslem studia kultury je pak vysvětlit, které psychické dispozice zapříčiňují utváření a rozšǐrení jednotlivých reprezentací a za kterých okolností dochází v procesu jejich vznikání $\mathrm{k}$ relativní stabilizaci jejich obsahu a formy. Zatímco jsou reprezentace neustále transformovány, tíhnou k jistým atrakčním pozicím, kolem kterých dochází pouze $\mathrm{k}$ omezeným proměnám, čímž nastává určitá stabilita. Tyto atrakční pozice mohou být jak transkulturní a všelidské, tak kulturně specifické a nestálé. Selektivní stabilizace navozená těmito atrakčními pozicemi je potom hlavní hybnou silou kulturní evoluce.

Ke konci 20. století kognitivní př́stupy rovněž zaměřily svou pozornost na studium náboženských jevů. Jedni z prvních badatelů, kteří se o jejich aplikaci v této oblasti pokusili, byli: Stewart Guthrie se svou prací o antropomorfismu (Guthrie 1980, 1993); Pascal Boyer s knihou o přirozenosti náboženských představ (Boyer 1994); Merlin Donald, Steven Mithen a Terrence Deacon se svými teoriemi o vývoji lidské mysli, symbolických reprezentací a původu náboženství (Donald 1991; Mithen 1996; Deacon 1997); E. Thomas Lawson a Robert N. McCauley se svou hypotézou rituální formy o vztahu mezi strukturou rituálu a intuicí lidí o účinnosti rituálu (Lawson, McCauley 1990, McCauley a Lawson 2002); a Harvey Whitehouse se svou teorií protikladných forem náboženského přenosu (Whitehouse 1992, 1995, 2004). Díky průkopnickým pracím těchto badatelů se v oblasti kognitivní religionistiky na prahu nového tisíciletí objevila další vlna nových publikací.

Propagátoři tohoto paradigmatu tvrdí, že navzdory kontextuálním odlišnostem, zdánlivě nekonečné variabilitě kulturních forem a projevů zdokumentovaných srovnávací vědou o náboženství, i náboženství podléhá omezením vyplývajícím z obecného uzpůsobení lidské mysli. Vlastnosti lidské mysli (např́klad pamět', pozornost, vědomí, teorie mysli), interakce mezi jednotlivci a mezi skupinami zachycená $\mathrm{v}$ dějinných etapách a proměnách dějin (např́iklad politické změny, války atd.) a rovněž podmínky materiálního světa, ve kterém žijeme, i s jeho specifickými geografickými podmínkami (např́klad dostupné zdroje potravy, geografická izolace atd.) aktivně tvarují a omezují lidské chování a jeho projevy (Whitehouse 2004). Náboženství není v tomto směru žádnou výjimkou. Náboženské chování je utvářeno stejnými mentálními kapacitami lidského mozku. Rovněž reprezentace náboženských aktivit spoléhají na stejné kognitivní mechanismy vlastní všem lidem, na mechanismy, které jsou uživány k reprezentaci jakéhokoli jiného jednání.

\section{Chybějící integrace}

Kognitivní obrat zakládá jednu $\mathrm{z}$ nejdůležitějších změn ve studiu náboženství v posledních několika desetiletích. Navzdory slibným počátkům však kognitivní religionistika ještě nedokázala přivodit paradigmatickou změnu, kterou slibovala, a studium náboženství tak zůstává fragmentarizované a nedostatečné. Ačkoli zájem badatelů studujících náboženství o lidskou psychiku pozvolna roste, stále se z větší části straní experimentálního výzkumu a velmi často nejsou schopni připustit, že uzpůsobení lidské mysli sehrává nějakou roli při omezování variability kulturních projevů. Danou oblast výzkumu nezř́ídka trápí radikální 
metodologický relativismus, podle kterého mohou být každá kultura a každé náboženství pochopeny pouze v rámci svých vlastních pravidel. Popřením důležitosti kulturních konstant, které by vyzdvihly smysluplnost proměnných prvků, tento postoj ve svém důsledku oslabuje pozici srovnávací religionistiky a opomíjí obecné psychické mechanismy, které podmiňují lidské chování. $\mathrm{K}$ těmto problémům se navíc přidružuje i neochota pokročit za explicitní reprezentace a zaměřit pozornost na implicitní fungování mysli. Mentální koncepty a procesy spojené s náboženskostí jsou mnohem komplikovanější záležitostí, než naznačují výpovědi samotných účastníků nebo domněnky, které mají věříí o svých vlastních představách. Jakkoli může být tato snaha důležitá, nestačí pouze popisovat, co lidé dělají a co ř́kají. Stejně tak důležité je podrobně popsat, do jaké míry jsou tyto explicitní projevy ovlivněny implicitními kognitivními procesy.

Přestože mnoho kognitivních vědců se nyní zaměřilo na studium náboženských představ a náboženského chování, ve většině př́ípadů studují předměty svého zájmu v omezených laboratorních podmínkách, aniž by věnovali dostatek pozornosti environmentálním a sociokulturním proměnným, které ovlivňují lidské chování. Někteří kognitivní vědci pak propagují jako teoretické východisko metodologický materialismus, $v$ jehož perspektivě jsou mysl a mozek jednou a téže věcí. Vše, co potřebujeme vědět o fungování mysli, se tedy můžeme dozvědět ze studia mozku v laboratoři, například s pomocí fMRI skeneru. Ačkoli souhlasím s prvním výchozím předpokladem, že mentální stavy jsou principiálně vzato stavy mozku, a ačkoli jsem si vědom pokroku, který byl učiněn v oblasti neurověd, domnívám se, že fungování mozku na fyzické úrovni, a to jak epistemologicky, tak technologicky, stále ještě nerozumíme dostatečně, a proto musíme do výzkumu začlenit i další roviny analýzy.

Mezi některými kognitivními vědci je rovněž běžný metodologický individualismus, který v lidech spatřuje pouhý soubor jednotlivců. Tento postoj implikuje, že to jediné, co musíme udělat pro to, abychom porozuměli kulturním jevům, je vysvětlit individuální chování (Thagard 2005). Tento názor pokládám za jednoduše naivní, nebot’ odmítá zohlednit fakt, že žádný jednotlivec neexistuje mimo společnost (kromě určitých vzácných patologických situací). A konečně, někteří kognitivní vědci se téměř exkluzivně zaměřili na studium implicitních procesů a odmítli důležitost explicitních představ a postojů (Whitehouse 2004). Tato pozice se ale jeví jako vnitřně rozporná. Pokud vyjdeme z premisy, že každá zdravá lidská mysl funguje podle stejných principů, a tím pádem všechny stejným způsobem vytváŕí implicitní koncepty, jak můžeme dostát našeho prvotního cíle vysvětlit kulturní variabilitu, pokud zavrhneme roli explicitního poznání?

Zdá se tedy, že navzdory průkopnickým snahám výše uvedených badatelů nebylo mezi zmíněnými dvěma tábory stále dosaženo skutečné integrace. To, co přetrvává, je existence dvou odlišných př́stupů ke studiu náboženství, jejichž proponenti na sebe navzájem pohlíží s podezrrívavostí a odmítají se zastánci druhého prrístupu spolupracovat. Pokud použijeme trefnou analogii E. Thomase Lawsona (který hovoř́ o psychologii, etnografii a historii), situace připomíná metodologickou bigamii, zatímco by ve skutečnosti měla být trojstrannou volnou láskou:

Bigamie je trojstranný vztah, na jehož vrcholu se nachází bigamista a v základně dva objekty bigamie. Stěžejně důležité pro tento trojstranný vztah je, že ani jeden z obou zúčastněných 
v základně trojúhelníku nic netuší o existenci toho druhého... Tato nevědomost nevěstí nic dobrého, a to jak v krátkodobé, tak dlouhodobé perspektivě, pokud je tato bigamie odhalena. Následné poznání obvykle znepřátelí všechny zainteresované. V trojstranné volné lásce každý z účastníků ví o existenci všech dalších. Pokud je zachován vzájemný respekt, situace nemusí vést ke konfliktu. (Lawson 2004: 2)

Vztah mezi studiem náboženství, humanitními vědami a kognitivními vědami byl bigamistický. Oba zúčastnění v základně trojúhelníku o sobě bud’to neví (nebo to alespoň předstírají), nebo se vůči sobě chovají se žárlivostí, podezíravostí a opovržením. Zdá se být zjevným, že takovýto vztah nemůže být prospěšný.

\section{Syntetický př́stup}

Situace si žádá nalezení př́stupu, který bude nejenom analytický, ale rovněž i syntetický. $\mathrm{V}$ tomto př́stupu nebudou tradiční metody humanitních věd a kognitivních věd v protikladu, ale budou se vzájemně doplňovat. Uznání důležitosti kognitivních faktorů na utváření lidského chování je plně slučitelné s existencí sociálních faktorů, a naopak. Všichni lidé sdílí stejný základní smyslový a neurální aparát, který poskytuje obecný biologický základ pro kulturní variabilitu (Thagard 2005). Náboženské chování neexistuje mimo kulturu a nemůže existovat bez jednotlivců. Je omezeno vlastnostmi lidského mozku a mysli přinejmenším stejně jako historickým a sociopolitickým vývojem. Kognice a jakékoli poznání neexistují izolovaně v neurálních stavech odehrávajících se v mozku, ani nejsou uvězněny v individuálních myslích, ale jsou uskutečňovány v interakci s ostatními jednotlivci (Hutchins 1995). Jakékoli ucelené studium náboženství (a všech ostatních kulturních jevů) by mělo vzít $\mathrm{v}$ úvahu alespoň tři roviny analýzy: biologickou/neurologickou (co se odehrává v individuálních mozcích), psychologickou (co se odehrává v individuální mysli) a sociální (co se odehrává mezi subjekty obdařenými individuální myslí). Společným jmenovatelem všech těchto tří domén je mozek, který nastavuje mantinely, $\mathrm{v}$ jejichž rámci operuje individuální mysl, a určuje parametry sociokulturních forem.

Životaschopnější akademické studium náboženství tedy bude multidisciplinární a metodologicky integrativní. Tradiční historiografické a etnografické metody, založené na analýze textů a zúčastněném pozorování, by neměly být v žádném př́padě nahrazeny, ale spiše doplněny o metody, teorie a technologie $\mathrm{z}$ oblasti prrírodních věd. Natolik intelektuálně náročný podnik musí zjevně zahrnovat spolupráci jdoucí např́íc jednotlivými obory. Napríiklad antropolog, který pracuje $\mathrm{v}$ terénu, bude informovat a zároveň konzultovat psychologa pracujícího v laboratoři, aby společně lépe pochopili chování, které studují, a metodologie, které potřebují použít. Nebo, bude-li to nutné, budou oba pracovat společně na přenosu laboratoře do terénu.

\section{Přenos laboratoře do terénu}

Jako př́íklady zmíním dva terénní výzkumy, které přenesly experimentální metody do terénu za účelem studia náboženského chování. První z výzkumů sestává z řady studií rituálů, které jsem provedl ve Španělsku spolu se svými kolegy z univerzity v Aarhusu (Konvalinka a kol. 
2011; Xygalatas a kol. 2013). Tento projekt spojil výzkumníky z tak rozdílných oblastí, jako jsou religionistika, antropologie, psychologie a bioinženýrství, kteří podnikli cestu do vesnice San Pedro Manrique, aby zde provedli výzkum místního rituálu chození po žhavém uhlí. Účelem tohoto výzkumu bylo prošetřit sadu parametrů, které se týkaly paměti a synchronního vzrušení mezi účastníky rituálu a přihlížejícími diváky.

Za použití specializovaného zařízení jsme během rituálu provedli fyziologická měření (srdečního tepu a elektrokardiografii) a následně jsme vedli podrobná interview s účastníky, která doplnila obsáhlou etnografickou studii. Jedním ze zajímavých zjišsění byla ostrá diskrepance mezi měřitelným stupněm fyziologického vzrušení účastníkủ během vlastní chůze po žhavém uhlí a jejich subjektivním vnímáním a vědomím tohoto stavu. Většina účastníků konkrétně vypovídala, že pocit’ovali zvýšené napětí před vlastní chůzí, ale ve chvíli, kdy kráčeli po žhnoucích uhlících, zažívali klid a vyrovnanost. Většina z nich dokonce tvrdila, že zakoušeli větší vzrušení při rozhovoru s tazatelem o chůzi po žhavých uhlících než během chůze samotné. Naše fyziologická měření nicméně dokládala něco jiného. Pro všechny zúčastněné byla vlastní chůze po žhavém uhlí (podle očekávání) zdaleka nejvzrušenější částí z celého průběhu rituálu. Míra vzrušení se během chůze dostávala mimo obvyklé hodnoty, když se nejvyšší naměřená hodnota srdečního tepu pohybovala v rozmezí 169 a 193 tepů za minutu, čímž většina účastníků překročila konvenčně udávanou bezpečnou hodnotu tepové frekvence.

Tato konkrétní zjištění poukazují na jednu důležitou věc: při naší snaze o porozumění lidskému chování se nemůžeme spoléhat výhradně na výpovědi našich subjektů nebo na naše vlastní interpretace. Znamenalo by to totiž ignorovat skutečnost, že lidé si nejsou vždy plně vědomi toho, jakým způsobem jejich tělo a mysl fungují. U výše zmíněného př́kladu by to znamenalo, že pokud bychom se člověka, který kráčel po žhavých uhlících, pouze zeptali, pod jakým stresem se během rituálu nacházel, byli bychom navedeni k velmi nepřesným fenomenologickým závěrům. Na straně druhé, každý kulturní jev a projev chování musí být studován $\mathrm{v}$ náležitém kontextu. Nebyl by problém podobný rituál zorganizovat $\mathrm{v}$ laboratorních podmínkách, vybrat skupinu účastníků a měřit jejich fyziologické reakce v průběhu chůze po žhavých uhlících. Získané výsledky by však byly z velké části irelevantní ve vztahu $\mathrm{k}$ rituálu studovanému ve Španělsku. Rituál v laboratoři by byl vykonáván mimo svůj obvyklý kontext. Jeho účastníci by nevěřili v jeho účinnost nebo by tomu, co provádějí, nepřikládali stejnou důležitost, což by negativně ovlivnilo smysl celého experimentu.

Je třeba poznamenat, že „přenesení laboratoře do terénu“ nemusí vždy znamenat využití sofistikovaných měricích př́strojů nebo invazivních technik. Ve skutečnosti největší výzvu představuje příprava ekologicky validních behaviorálních experimentů „v reálném světě“, které se zaměřují na stejné aspekty chování, jež byly předmětem studia etnografů v průběhu minulého století. Laboratorní metody studia lidského chování jsou založeny na standardních vědeckých principech zahrnujících pozorování a experimentování, které slouží ke sběru měřitelných důkazů za účelem testování specifických hypotéz; ty jsou empiricky ověritelné a jejich ověření je opakovatelné.

V oblasti studia náboženství se například můžeme setkat s rozšiřeným názorem, že kolektivní rituály podporují skupinovou solidaritu (Durkheim 1912). Tato představa se zdá být intuitivně věrohodnou a skutečně se velmi dobře shoduje s laickým i antropologickým 
pozorováním kulturní dynamiky. Pokud však nenalezneme nějaký způsob, jak prokázat validitu této představy empirickým způsobem, nenabízí nám nic jiného než pouhý abstraktní filosofický koncept, který velmi často končí v nástrahách kruhové argumentace při interpretaci etnografických dat. Pokud chceme $\mathrm{z}$ této představy něco získat, musíme provést její operacionalizaci a podrobit ji empirickému testu.

Richard Sosis a Bradley Ruffle (2003) se právě o něco takového pokusili tím, že připravili terénní experiment, kterým otestovali tvrzení, že účast na kolektivních rituálech povzbuzuje vnitroskupinovou kooperaci mezi obyvateli izraelských kibuců. Jejich výchozí hypotézou bylo, že př́slušníci náboženských kibucủ budou vykazovat vyšší míru kooperace než př́slušníci sekulárních kibuců. Pracovali rovněž s předpokladem, že nábožensky aktivní muži budou kvůli své častějšś účasti na kolektivních rituálech vykazovat větší míru kooperace v porovnání s nábožensky aktivními ženami a že ti jednotlivci, kteř́ se rituálů účastnili častěji, budou ochotnější spolupracovat, než ti, kteří se jich účastnili méně.

Aby tyto hypotézy otestovali, Sosis a Ruffle použili důmyslné ekonomické hry, během které byly dvojice členů stejného kibucu, kteří navzájem neznali totožnost svého protějšku, postaveni před variantu dilematu veřejného statku. $V$ této hře každý hráč samostatně a nezávisle rozhodoval o tom, jak velkou částku z obálky obsahující 100 šekelů (ekvivalent príbližně tř́ až pětidenního výdělku) si přeje ponechat. Poté, co oba hráči učinili své rozhodnutí, částka, která zbyla $\mathrm{v}$ obálce (pokud vůbec), byla navýšena o $50 \%$ a rozdělena mezi oba účastníky. Pokud však částka, kterou si oba členové dvojice rozhodli ponechat, prrekročila 100 šekelů, ani jeden neobdržel žádné další peníze. Nejvýhodnější strategií, jak získat maximální částku, pro oba hráče tedy bylo v obálce ponechat všechny peníze, a tím pádem nakonec obdržet po 75 šekelech (100 šekelů navýšeno o $50 \%$ rozděleno mezi oba členy dvojice). Na spolupráci druhého člena dvojice však nelze automaticky spoléhat. Pokud jeden z dvojice kooperuje a druhý spolupráci odepře, spolupracující tratí. Pokud ani jeden z hráčů nespolupracuje, prohrávají oba. Č́stka, kterou si každý z hráču z obálky bere, je tedy vyjádřením míry ochoty hráče spolupracovat. Čím více spolupracující hráč/hráčka je, tím méně peněz z obálky si ponechává, $\mathrm{v}$ důvěře, že jeho/její protějšek se zachová stejným způsobem.

Výsledky tohoto experimentu prokázaly, že nábožensky aktivní muži byli skutečně kooperativnější než nenáboženští muži a nábožensky aktivní ženy a že mezi četností návštěv synagogy u mužů a množstvím odebraných peněz z obálky existuje negativní korelace. Získaná data tak podpořila hypotézu, že kolektivní rituály podporují vnitroskupinovou spolupráci. Co je však důležité, je skutečnost, že - nehledě na výsledky a jejich interpretaci - experiment byl proveden takovým způsobem, který zajistil jak jeho kontrolu, tak ekologickou validitu. Zároveň je možné tento experiment zopakovat $\mathrm{v}$ jiných kulturních kontextech, což zajišt'uje možnost falsifikace výchozích hypotéz.

\section{Závěry}

Domnívám se, že výše uvedené prríklady terénních experimentů poskytly dobrou ukázku toho, co se zdá být slibným modelem studia náboženského chování. Terénní a experimentální metody tradičně fungovaly odděleně jako nesouvisející nebo dokonce vzájemně neslučitelné postupy. $\mathrm{V}$ důsledku této situace experimentalisté vnímali antropologické metody 
jako netestovatelné a vědecky neoveřitelné a antropologický výzkum pak pokládali za př́liš povrchní na to, aby dokázal skutečně přispět k řešení konkrétních problémů. Antropologové na oplátku často nahlíželi na experimentální výzkum jako odtržený od reálného světa a založený na datech získaných mimo reálný kontext ve „sterilizovaném“ laboratorním prostředí postrádajícím ekologickou validitu.

Situace vyžaduje spíše syntetický a kolektivní př́stup, který bude kombinovat silné stránky různých disciplín tak, aby byly překonány jejich slabiny. Cílem tohoto snažení je posunout se od hermeneuticky orientovaného studia náboženství $\mathrm{k}$ vědeckému. Musí proto nabídnout empiricky testovatelné a např́íc kulturami ověřitelné teorie, které poskytnou neetnocentricky zakotvenou platformu k pochopení kulturní variability, a tím následně i společnou bázi pro srovnávací studium náboženství (Martin 2005). Domnívám se, že takovýto model nabídne srovnávacímu studiu náboženství silnější teoretické zázemí a propojí síly jednotlivých disciplín v jeden smysluplný celek.

Přeložil Aleš Chalupa

\section{Literatura}

ATRAN, Scott. Cognitive Foundations of Natural History: Towards an Anthropology of Science. 1. vyd. Cambridge: Cambridge University Press, 1990. ISBN 9780521438711.

BAMBROUGH, Renford. Editorial: Subject and Epithet. Philosophy, 1980, roč. 55, č. 213, s. 289-290. ISSN 0031-8191.

BERLIN, Brent a Paul KAY. Basic Color Terms: Their Universality and Evolution. 1. vyd. Berkeley: University of California Press, 1969. ISBN 1575861623.

BOYER, Pascal. The Naturalness of Religious Ideas: A Cognitive Theory of Religion. 1. vyd. Berkeley: University of California Press, 1994. ISBN 0520911628.

BROADBENT, Donald. Perception and Communication. 1. vyd. Oxford: Pergamon, 1958. ISBN 0080090907.

BROWN, Cecil H. Language and Living Things: Uniformities in Folk Classification and Naming. 1. vyd. New Brunswick, NJ: Rutgers University Press, 1984. ISBN 0813510082.

DEACON, Terrence. The Symbolic Species: The Co-Evolution of Language and the Human Brain. 1. vyd. London: Penguin, 1997. ISBN 0393317544.

DONALD, Merlin. Origins of the Modern Mind: Three Stages in the Evolution of Culture and Cognition. 1. vyd. Cambridge, MA: Harvard University Press, 1991. ISBN 0674644840.

DURKHEIM, Émile. Les Formes Élémentaires de la Vie Religieuse. 1. vyd. Paris: Alcan, 1912.

ELIADE, Mircea. Images and Symbols: Studies in Religious Symbolism (trans. Philip Mairet). 1. vyd. Princeton: Princeton University Press, 1961. ISBN 069102068X.

GUTHRIE, Stewart. A Cognitive Theory of Religion. Current Anthropology, 1980, roč. 21, č. 2, s. 181-203. ISSN 0011-3204.

GUTHRIE, Stewart. Faces In the Clouds: A New Theory of Religion. 1. vyd. Oxford: Oxford University Press, 1993. ISBN 0195098919.

HAYS, Terrence. Ndumba Folkbiology and General Principles of Ethno-botanical Classification and Nomenclature. American Anthropologist, 1983, roč. 85, č. 3, s. 592-611. ISSN 1548-1433.

HUTCHINS, Edwin. Cognition in the Wild. 1. vyd. Cambridge, MA: MIT Press, 1995. ISBN 0262082314.

CHOMSKY, Noam. Syntactic Structures. 1. vyd. The Hague: Mouton, 1957. ISBN 9027933855. 
CHOMSKY, Noam. A Review of B. F. Skinner's Verbal Behavior. Language, 1959, roč. 35, č. 1, s. $26-58$. ISSN 0097-8507.

CHOMSKY, Noam. Knowledge of Language: Its Nature, Origin, and Use. 1. vyd. New York: Praeger, 1986. ISBN 0275900258.

JAMES, William. The Varieties of Religious Experience. 2. vyd. New York: Mentor, 1958.

KONVALINKA, Ivana, Dimitris XYGALATAS, Joseph BULBULIA, Uffe SCHJØDT, Else-Marie JEGINDØ, Sebastian WALLOT, Guy VAN ORDEN a Andreas ROEPSTORFF. Synchronized Arousal Between Performers and Related Spectators in a Fire-walking Ritual. Proceedings of the National Academy of Sciences, 2011, roč. 120, č. 20, s. 8514-8519. ISSN 1091-6490.

LAWSON, E. Thomas. Ritual as Language. Religion: A Journal of Religion and Religions, 1976, roč. 6, č. 2, s. 123-139. ISSN 0048-721X.

LAWSON, E. Thomas a Robert N. McCAULEY. Rethinking Religion: Connecting Cognition and Culture. Cambridge: Cambridge University Press, 1990. ISBN 0521438063.

LAWSON, E. Thomas. The Wedding of Psychology, Ethnography, and History: Methodological Bigamy or Tripartite Free Love? In WHITEHOUSE, Harvey a Luther H. MARTIN (eds.). Theorizing Religions Past: Archaeology, History, and Cognition. 1. vyd. Walnut Creek: AltaMira Press, 2004, s. 1-5. ISBN 0759106215.

MARTIN, Luther H. Comparative Religion. In HINNELLS, John (ed.). The Routledge Companion to the Study of Religion. 1. vyd. New York: Routledge, 2005, s. 205-222. ISBN 0415333113.

McCARTHY, John, Paul W. ABRAHAMS, Daniel J. EDWARDS, Timothy P. HART a Michael I. LEVIN. LISP 1.5. Programmer's Manual. 1. vyd. Cambridge: MIT Press, 1962. ISBN 0262130114.

McCARTHY, John, John HAYES a Patrick HAYES. Some Philosophical Problems from the Standpoint of Artificial Intelligence. In MELTZER, Bernard a Donald MICHIE (eds.). Machine Intelligence. 1. vyd. Edinburgh: Edinburgh University Press, 1969, s. 26-45. ISBN 0852240627.

McCAULEY, N. Robert a E. Thomas LAWSON. Bringing Ritual to Mind: Psychological Foundations of Cultural Forms. 1. vyd. Cambridge: Cambridge University Press, 2002. ISBN 9780521016292.

McCUTCHEON, Russell. Manufacturing Religion: The Discourse of Sui Generis Religion and the Politics of Nostalgia. 1. vyd. Oxford: Oxford University Press, 1997. ISBN 0195355687.

MILLER, George. The Magical Number Seven, Plus or Minus Two: Some Limits on Our Capacity for Processing Information. The Psychological Review, 1956, roč. 63, č. 2, s. 81-97. ISSN 0033-295X.

MINSKY, Marvin. Neural Nets and the Brain Model Problem. Ph.D. dissertation, Princeton: Princeton University Press, 1954.

MITHEN, Steven. The Prehistory of the Mind: The Cognitive Origins of Art and Science. 1. vyd. London: Thames and Hudson, 1996. ISBN 0500281009.

NEWELL, Allen a Herbert A. SIMON. Human Problem Solving. 1. vyd. Eaglewood Cliffs: Prentice-Hall, 1972. ISBN 0134454030.

NEWELL, Allen, J., Cliff SHAW a Herbert A. SIMON. Elements of a Theory of Human Problem Solving. Psychological Review, 1958, roč. 65, č. 3, s. 151-166. ISSN 0033-295X.

OTTO, Rudolf, The Idea of the Holy. 1. vyd. Oxford: Oxford University Press, 1923.

PALS, Daniel L. Is Religion a Sui Generis Phenomenon? Journal of the American Academy of Religion, 1987, roč. 55, č. 2, s. 259-282. ISSN 0002-7189.

PYYSIÄINEN, Ilkka. Magic, Miracles, and Religion: A Scientist's Perspective. 1. vyd. Walnut Creek, CA: AltaMira Press, 2004. ISBN 0759106630.

SHARMA, Arvind. To the Things Themselves: Essays on the Discourse and Practice of the Phenomenology of Religion. 1. vyd. Berlin: Walter de Gruyter, 2001. ISBN 3110169568.

SIMON, Herbert A. The Sciences of the Artificial. 1. vyd. Cambridge, MA: MIT Press, 1969. ISBN 0262691914. 
SKINNER, Burrhus Frederic. The Behaviour of Organisms: An Experimental Analysis. 1. vyd. New York: Appleton-Century-Crofts, 1938. ISBN 1583900071.

SOSIS, Richard a Bradley RUFFLE. Religious Ritual and Cooperation: Testing for a Relationship on Israeli Religious and Secular Kibbutzim. Current Anthropology, 2003, roč. 44, č. 5, s. 713-722. ISSN 0011-3204.

SPERBER, Dan. Rethinking Symbolism (trans. by Alice E. Morton). 1. vyd. Cambridge: Cambridge University Press, 1975. ISBN 0521099676.

SPERBER, Dan. Explaining Culture: A Naturalistic Approach. 1. vyd. Oxford: Blackwell, 1996. ISBN 0631200452.

STAAL, Frits. The Meaninglessness of Ritual. Numen, 1979, roč. 26, č. 1, s. 2-22. ISSN 0029-5973.

STAAL, Frits. Ritual Syntax. In NAGATOMI, Masatoshi, Bimal K. MATILAL a J. Moussaieff MASSON (eds.). Sanskrit and Indian Studies: Essays in Honour of Daniel H. H. Ingalls. 1. vyd. Dordrecht: D. Reidel, 1979, s. 119-142. ISBN 9027709912.

THAGARD, Paul. Mind: Introduction to Cognitive Science. 1. vyd. Cambridge, MA: MIT Press, 2005. ISBN 026270109X.

TURING, Alan M. Computing Machinery and Intelligence. Mind, 1950, roč. 59, č. 236, s. 433-460. ISSN 0026-4423.

WHITEHOUSE, Harvey. Memorable Religions: Transmission, Codification and Change in Divergent Melanesian Contexts. Man, 1992, roč. 27 (n. s.), č. 4, s. 777-797. ISSN 0025-1496.

WHITEHOUSE, Harvey. Inside the Cult: Religious Innovation and Transmission in Papua New Guinea. 1. vyd. Oxford: Oxford University Press, 1995. ISBN 0198279817.

WHITEHOUSE, Harvey. Modes of Religiosity: A Cognitive Theory of Religious Transmission. Walnut Creek: AltaMira Press, 2004. ISBN 0759106150.

XYGALATS, Dimitris, Uffe SCHJØDT, Joseph BULBULIA, Ivana KONVALINKA, Else-Marie JEGINDØ, Paul REDDISH, Armin W. GEERTZ a Andreas ROEPSTORFF. Autobiographical Memory in a Fire-Walking Ritual. Journal of Cognition and Culture, 2013, roč. 13, č. 1-2, s. 1-16. ISSN 1567-7095.

\section{Autor}

Dimitris Xygalatas je odborným asistentem Ústavu kultury a společnosti univerzity v dánském Aarhusu a ředitelem výzkumu v Laboratoři pro experimentální výzkum náboženství (LEVYNA) při Ústavu religionistiky Filozofické fakulty MU. Je autorem monografie The Burning Saints: Cognition and Culture in the Fire-Walking Rituals of the Anastenaria (London: Acumen 2012) a spolu s Williamem W. McCorklem, Jr. editoval sborník Mental Culture: Classical Social Theory and the Cognitive Science of Religion (London: Acumen 2012). Kontakt: xygalatas@mac.com 